\title{
NUTRIENT LOAD ESTIMATION OF NONPOINT SOURCE POLLUTION FOR HONG KONG REGION
}

\author{
H.E. $\mathrm{Li}^{1}$, J.H.W. Lee ${ }^{2}$, A. Koenig ${ }^{2}$, A.W. Jayawardena ${ }^{2}$ \\ ${ }^{1}$ Environmental Science Institute, Xi'an University of Technology, Xi'an 710048, Shaanxi Province, P.R.China, \\ Lhuaien@mail.xaut.edu.cn \\ ${ }^{2}$ Department of Civil Engineering, The University of Hong Kong, Pokfulam Road, Hong Kong, P.R.China
}

\begin{abstract}
:
Red tides and eutrophication have been frequently observed over the past two decades in coastal waters around Hong Kong, which are caused by many factors and one of them is the nutrient from nonpoint source pollution (NSP). This paper concentrates on the nutrients carried by river flow from watersheds. Since there are no systematical data sets of nonpoint source pollution in Hong Kong, monthly river water quality measurements, rainfall and river flow data, land uses, and other related information are used to analyze the characteristics of NSP and estimate the nutrient loads for Hong Kong region. Main achievements are as follows: firstly, besides mean concentration for single land use, the concept of integrated mean concentration for mixed land uses were proposed and applied. Secondly, mean concentrations were carried out for different land uses (agriculture, town, grassland, shrubland and woodland), each Water Control Zone, and Hong Kong region. Thirdly, the annual nutrient loads were estimated, for the first time in this paper, with various methods for the whole area of Hong Kong, and about 8000 tons of TN and 1500 tons TP are transported into coastal waters from Hong Kong's land in 1998.
\end{abstract}

\section{Key words: Hong Kong; Integrated mean concentration; Load estimation; Nonpoint source pollution; Nutrients}

\section{INTRODUCTION}

Red tides have been frequently observed over the past two decades in costal waters (bays) around Hong Kong, and nutrient enrichment in the waters is one of the main reasons. Usually, the nutrients can come from internal and external sources. For Hong Kong waters, main external sources include: effluent from wastewater treatment plant (point source), river discharge (point and nonpoint source), and dry and wet deposition of air to the water surface (nonpoint source), return flow of street washing sea-water, etc.

In order to understand and resolve the problems caused by nonpoint source pollution, especially to predict the load of nonpoint source pollution and the effectiveness of various control measures, the loading and modeling of nonpoint source pollution has been one of the most important fields on nonpoint source pollution research for about 30 years. However, there are only few studies on the nonpoint source pollution for Hong Kong area. A Pilot study on urban storm water pollution, 3 events were monitored at 4 sites in 1998 (Chen, et al., 1999). In that study, the EMC (event mean concentration) and FFC (first flush concentration) were estimated also, and the results showed that there were obvious first flush phenomena. However, the measured concentrations of that study might be smaller than actual values since only fewer storm events were measured, and what is more, no heavy storm events. Another monitoring study was carried out at two stations, with different land uses, on Ho Chung River (Lee, 1990), but stormwater samples were collected only from one storm event, the rainfall of $32.5 \mathrm{~mm}$. Peart and Jayawardena (1991) analyzed the storm period water quality changes in a small stream. Arega (1999) estimated the total nitrogen load to Tolo Harbour.

Therefore, this study will concentrate on the nutrients carried by runoff from watershed. Based on limited data and information, the characteristics of nonpoint source pollution from Hong Kong streams were investigated and the nutrient loads were estimated. Apart from the mean concentration for single land use, the integrated mean concentrations were proposed and studied in detail for the Hong Kong region, and Water Control Zones in Hong Kong. Then, Nutrient loads for the whole area of Hong Kong were estimated.

\section{MATERIALS AND APPROACHES}

The main materials and data sources related to nonpoint source pollution in Hong Kong are as follows: monthly river water quality measurements from EPD (Environmental Protection Department, HKSAR); daily and monthly stream flow from WSD (Water Supplies Department, HKSAR); monthly rainfall from WSD and Hong Kong Observatory; and land uses, water pollution control (SMP, Livestock), etc.

The loading techniques for nonpoint source pollution should be compatible with the available data (Letcher, et al., 2002). Since there are no systematical data sets of nonpoint source pollution in Hong Kong region, the direct load estimation methods and some simple methods will be used in this paper, and no modeling efforts were made. 


\section{BASIC CHARACTERISTICS OF NSP IN HONG KONG}

As the basic characteristics of NSP, mean concentrations for different rivers, different land uses, and different Water Control Zones in Hong Kong will be analyzed in this part. At the same time, mean concentrations are also the base of load estimation. For these purposes, 37 catchments/rivers, each of which had nearest water quality station to the outlet with sample stream-flow measurements, were selected. The data of 1998 was selected as the analysis basis since the rainfall of 1998 is close to the mean annual rainfall, and all kinds of data in Hong Kong is available to this year.

37 selected rivers/catchments is listed in Table 1. Usually, the sample frequency is monthly. But a few stations have sparse samples, and there are a few of stations without flow measurement that can't be included in the calculation. In total there are 312 sets of sample measurements in 1998.

\section{Analysis of mean concentration \\ Concentration in each river}

To identify the impact of land use and other factors on nonpoint source pollution and to provide the basis for following analysis, it is necessary to calculate the average and flow-weighted mean concentrations for each river. The obtained results show that: for heavy polluted streams, the average concentrations are larger than flow-weighted concentrations as the samples in wet season have bigger flow rate and lower concentrations; and for other streams, there are no evident differences between two kinds of concentrations. Since the space is limited, only the results of flow-weighted mean concentration are shown in Table 1. It can be seen that the higher mean concentrations emerged in New Territories, especially the rivers to Deep Bay, Tuen Mun River to North Western, and the Lam Tsuen River to Tolo Harbour. The other rivers have lower concentrations. Actually, the distribution of mean concentrations reflected the comprehensive influences of land use, the progress of Sewerage Master Plan (SMP), and livestock waste control zones in Hong Kong region. From the map of land use in Hong Kong, agricultural land use, including 2800 livestock farms, mainly distributes in the watersheds of Kam Tin River, River Ganges, River Indus, River Beas, Yuen Long Creeek and Lam Tsuen River. At the same time, in 1998, the SMP in these areas had not been launched or just on its beginning (Table 2). For livestock waste control, most of the New Territories belongs to Control area, the lowest level, instead of higher level of prohibition and restriction. And there were unsewered villages in these areas in 1998 (EPD, 2000).

\section{Mean concentration of different land uses}

According to the land uses and water quality measurements in Hong Kong, the land uses are divided into five kinds: urban and town (developed land), agriculture, grassland, shrubland, and woodland. Their areas can be got from Hong Kong Year Book (ISD, 2000). From the map and data of land use in Hong Kong, the land uses in the catchment for above 37 rivers can be identified. There are mixed land uses in most catchments, but the catchments with only one main kind of land use can be found. Together with the results in Table 1, the average concentration of each land use type can be achieved (Table 3).

Compared with the local measurements for the land use of town (Chen, et al., 1999 and Lee, 1990), this study (Table 3) got much larger values of TN and TP. The average concentration of town in Table 3 comes from the results of Yuen Long Creek and Tuen Mun River. But there were unsewered villages in Tuen Mun River TN1 and wastes from livestock farms in Yuen Long Creek (EPD,2000), and no such effects for the monitoring sites in Chen's study. Another possible reason is that the EMC was obtained from only a few rainfall events, and no heavy storm events were included in that study (Chen, et al., 1999).

Compared with the literature values (such as Novotny and Olem 1994, Frink 1991), the concentrations of Agriculture and Town of this study (Table 3) are higher, and the results for grassland and woodland are similar. The values of Agriculture in Table 3 have the same magnitude as land applied dairy manure (Novotny and Olem 1994), which demonstrates the harmful impact of livestock farms on river water quality in New Territories, Hong Kong. As pointed out above, the higher concentrations for Agriculture and Town in Table 3 are related to livestock farms and unwewered villages.

Following conclusions can be summarized from above analysis: firstly, the concentrations of Agriculture in Table 3 can be mainly used in New Territories, and actually, the agricultural land, including livestock farms, distributes mainly in New Territories also. Next, the concentrations of Town in Table 3 can be used only for areas with unwewered villages, such $\mathbf{s}$ Yuen Long, North District, Tuen Mun, and Tai Po. For other town and urban areas, the concentrations of Chen's study can be used. And lastly, the concentrations of grassland, shrubland and woodland in Table 3 can be used for the whole area of Hong Kong region.

\section{Integrated mean concentration \\ Integrated mean concentration for Hong Kong region}

Usually, the mean concentration is related to single land use (Novotny and Olem, 1994). But in Hong Kong, there are no measurements of water quality for single land use. Actually, the mean concentration of each stream in Table 1 reflects the integrated effects of mixed land uses in its catchment. That is to say, it is a kind of integrated or mixed mean concentration for mixed land uses in a catchment. So, the key point of the concept of integrated mean concentration is that it reflects the influence of mixed land uses. If we extend the concept of catchment to higher level, such as Water Control Zone (WCZ) or even to the whole Hong Kong region, then we can define the concept of integrated mean concentration for a zone or the region with the same way. Once integrated mean concentration is determined, it can be applied to estimating the load of 
nonpoint source pollution at this level if rainfall-runoff is given. On the other hand, since there are many but extremely small streams in Hong Kong or in a WCZ, it is not easy to estimate the total load by summarizing the load of each stream. So, the concept of integrated mean concentration for WCZ is important and practical for water pollution control in Hong Kong.

Table 1 Flow-weighted mean concentration and average flow for each river, 1998

\begin{tabular}{|c|c|c|c|c|c|c|c|c|}
\hline \multirow{2}{*}{ Order } & \multirow{2}{*}{ RIVER } & \multirow{2}{*}{$\begin{array}{c}\text { Station } \\
\text { Name }\end{array}$} & $\mathrm{BOD}_{5}$ & $\mathrm{NO}_{3}$ & TKN & TP & $\mathrm{TN}$ & Flow \\
\hline & & & $(\mathrm{mg} / \mathrm{l})$ & $(\mathrm{mg} / \mathrm{l})$ & $(\mathrm{mg} / \mathrm{l})$ & $(\mathrm{mg} / \mathrm{l})$ & $(\mathrm{mg} / \mathrm{l})$ & $\left(\mathrm{m}^{3} / \mathrm{s}\right)$ \\
\hline 1 & HA PAK NAI STREAM & $\overline{\mathrm{DB} 1}$ & 1.70 & 0.13 & 0.08 & 0.02 & 0.22 & 0.018 \\
\hline 2 & KAM TIN RIVER & KT2 & 41.42 & 0.04 & 34.16 & 7.52 & 34.20 & 0.241 \\
\hline 3 & NGAU HOM SHA STREAM & DB6 & 17.76 & 0.52 & 3.28 & 0.65 & 3.80 & 0.014 \\
\hline 4 & TSANG KOK STREAM & DB8 & 3.26 & 0.36 & 0.27 & 0.05 & 0.63 & 0.027 \\
\hline 5 & PAK NAI STREAM & DB3 & 1.30 & 0.42 & 0.43 & 0.15 & 0.85 & 0.022 \\
\hline 6 & RIVER BEAS & RB3 & 24.74 & 0.45 & 6.87 & 1.31 & 7.32 & 0.769 \\
\hline 7 & RIVER GANGES & GR1 & 14.60 & 0.60 & 8.48 & 2.42 & 9.08 & 0.431 \\
\hline 8 & RIVER INDUS & IN3 & 4.24 & 0.70 & 1.25 & 0.64 & 1.95 & 0.198 \\
\hline 9 & SHEUNG PAK NAI STREAM & DB5 & 1.11 & 0.20 & 0.17 & 0.03 & 0.37 & 0.037 \\
\hline 10 & TAI SHUI HANG STREAM & DB2 & 1.12 & 0.11 & 0.10 & 0.03 & 0.21 & 0.092 \\
\hline 11 & TIN SHUI WAI NULLAH & TSR2 & 4.55 & 0.66 & 1.83 & 0.22 & 2.49 & 0.096 \\
\hline 12 & YUEN LONG CREEK & YL3 & 93.44 & 0.06 & 31.47 & 6.68 & 31.53 & 0.440 \\
\hline 13 & YUEN LONG CREEK & YL4 & 101.42 & 0.01 & 11.66 & 1.58 & 11.67 & 0.300 \\
\hline 14 & TSENG I & JR11 & 2.29 & 1.79 & 0.52 & 0.27 & 2.31 & 0.262 \\
\hline 15 & TUEN MUN RIVER & TN1 & 44.83 & 0.86 & 8.59 & 1.57 & 9.46 & 0.117 \\
\hline 16 & TUEN MUN RIVER & TN2 & 6.71 & 1.87 & 1.21 & 1.00 & 3.08 & 0.085 \\
\hline 17 & TUNG CHUNG RIVER & $\mathrm{TC} 1$ & 1.00 & 0.13 & 0.08 & 0.02 & 0.21 & 0.037 \\
\hline 18 & TUNG CHUNG RIVER & $\mathrm{TC} 2$ & 1.19 & 0.04 & 0.23 & 0.11 & 0.27 & 0.034 \\
\hline 19 & HO CHUNG RIVER & PR2 & 1.00 & 0.27 & 0.18 & 0.04 & 0.45 & 0.165 \\
\hline 20 & SHA KOK MEI STREAM & PR5 & 1.17 & 0.75 & 0.30 & 0.09 & 1.05 & 0.177 \\
\hline 21 & TAI CHUNG HAU STREAM & PR7 & 1.00 & 0.60 & 0.21 & 0.07 & 0.81 & 0.556 \\
\hline 22 & MUI WO RIVER & MW1 & 1.17 & 0.33 & 0.13 & 0.12 & 0.46 & 0.070 \\
\hline 23 & MUI WO RIVER & MW4 & 3.02 & 0.12 & 0.67 & 0.17 & 0.78 & 0.260 \\
\hline 24 & MUI WO RIVER & MW5 & 1.30 & 0.17 & 0.42 & 0.10 & 0.59 & 0.048 \\
\hline 25 & LAM TSUEN RIVER & TR12 & 2.96 & 3.73 & 1.38 & 1.18 & 5.11 & 0.022 \\
\hline 26 & LAM TSUEN RIVER & TR12E & 7.35 & 0.49 & 0.81 & 0.68 & 1.29 & 0.046 \\
\hline 27 & SHAN LIU STREAM & TR4 & 1.50 & 0.45 & 0.32 & 0.12 & 0.77 & 0.031 \\
\hline 28 & SHING MUN RIVER & KY1 & 1.00 & 0.74 & 0.15 & 0.18 & 0.89 & 0.016 \\
\hline 29 & SHING MUN RIVER & TR17 & 26.28 & 0.56 & 1.76 & 0.47 & 2.32 & 0.065 \\
\hline 30 & SHING MUN RIVER & TR19 & 6.71 & 0.95 & 1.43 & 0.20 & 2.38 & 0.295 \\
\hline 31 & SHING MUN RIVER & TR20B & 1.00 & 1.09 & 0.71 & 0.45 & 1.80 & 0.133 \\
\hline 32 & SHING MUN RIVER & TR23L & 1.83 & 0.25 & 0.20 & 0.06 & 0.45 & 0.134 \\
\hline 33 & TAI PO KAU STREAM & TR14 & 1.81 & 0.49 & 0.59 & 0.19 & 1.09 & 0.159 \\
\hline 34 & TAI PO RIVER & TR13 & 3.97 & 0.72 & 0.54 & 0.14 & 1.25 & 0.186 \\
\hline 35 & KAU WA KENG STREAM & KW3 & 7.62 & 1.64 & 1.93 & 0.48 & 3.57 & 0.014 \\
\hline 36 & SAM DIP TAM STREAM & TW2 & 9.40 & 0.86 & 2.15 & 0.28 & 3.01 & 0.037 \\
\hline 37 & PAI MIN KOK STREAM & AN2 & 2.44 & 1.63 & 0.74 & 0.22 & 2.38 & 0.011 \\
\hline
\end{tabular}

Table 2 Schedule of some SMPs

\begin{tabular}{|l|c|c|}
\hline SMP areas & Commencement & Completion \\
\hline \hline Yuen Long \& Kam Tin & 1999 & 2008 \\
\hline North District & 1999 & 2009 \\
\hline Tuen Mun & 1995 & 2006 \\
\hline
\end{tabular}


Table 3 Average concentrations for different land uses

\begin{tabular}{|l|r|r|r|r|r|r|r|c|}
\hline \multirow{2}{*}{ Land Use } & \multicolumn{1}{|c|}{$\mathrm{BOD}_{5}$} & \multicolumn{1}{c|}{$\mathrm{COD}$} & $\mathrm{NH}_{4}$ & \multicolumn{1}{c|}{$\mathrm{NO}_{3}$} & \multicolumn{1}{c|}{$\mathrm{TKN}$} & \multicolumn{1}{c|}{$\mathrm{PO}_{4}$} & \multicolumn{1}{c|}{$\mathrm{TP}$} & $\mathrm{TN}$ \\
\cline { 2 - 9 } & $(\mathrm{mg} / \mathrm{l})$ & $(\mathrm{mg} / \mathrm{l})$ & $(\mathrm{mg} / \mathrm{l})$ & $(\mathrm{mg} / \mathrm{l})$ & $(\mathrm{mg} / \mathrm{l})$ & $(\mathrm{mg} / \mathrm{l})$ & $(\mathrm{mg} / \mathrm{l})$ & $(\mathrm{mg} / \mathrm{l})$ \\
\hline \hline Agriculture & 28.0 & 51.1 & 16.75 & 0.32 & 21.32 & 3.50 & 4.97 & 21.64 \\
\hline Town & 79.9 & 99.4 & 12.26 & 0.31 & 17.24 & 2.03 & 3.28 & 17.55 \\
\hline Grassland & 10.5 & 22.3 & 0.4 & 1.25 & 1.29 & 0.10 & 0.47 & 2.54 \\
\hline Shrubland & 3.2 & 14.9 & 0.29 & 0.70 & 0.84 & 0.11 & 0.18 & 1.54 \\
\hline Woodland & 1.6 & 17.6 & 0.08 & 0.35 & 0.41 & 0.04 & 0.17 & 0.77 \\
\hline
\end{tabular}

Since the selected 37 rivers /catchments is a good representative of Hong Kong region, the integrated average concentrations and flow-weighted mean concentrations for Hong Kong region in 1998 can be carried out on the basis of Table 1, and shown in Table 4. At the same time, the calculations were also done for dry season, wet season, and samples during flood events, respectively, Table 5. Flood samples can be chosen from monthly measurements by comparing the sample date with the mean daily flow graph recorded at hydrological stations in the region.

Table 4 Integrated mean concentrations of Hong Kong region in 1998

\begin{tabular}{|c|c|c|c|c|c|c|c|c|c|}
\hline Method & $\mathrm{BOD}_{5}$ & $\mathrm{COD}$ & $\mathrm{NH}_{4}$ & $\mathrm{NO}_{3}$ & $\mathrm{TKN}$ & $\mathrm{PO}_{4}$ & $\mathrm{TP}$ & $\mathrm{TN}$ & $\mathrm{Q}$ \\
\hline \hline Average & 16.2 & 27.6 & 3.75 & 0.77 & 5.26 & 0.78 & 1.20 & 6.03 & 0.158 \\
\hline Weighted mean & 23.4 & 35.7 & 4.92 & 0.57 & 6.89 & 0.95 & 1.49 & 7.46 & \\
\hline
\end{tabular}

Table 5 Integrated mean concentrations of Hong Kong region for dry and wet season, and flood samples

\begin{tabular}{|c|c|c|c|c|c|c|c|c|c|c|}
\hline Method & Type & $\mathrm{BOD}_{5}$ & $\mathrm{COD}$ & $\mathrm{NH}_{4}$ & $\mathrm{NO}_{3}$ & $\mathrm{TKN}$ & $\mathrm{PO}_{4}$ & $\mathrm{TP}$ & $\mathrm{TN}$ & FLOW \\
\hline \hline \multirow{4}{*}{ Average } & Dry & 22.8 & 42.2 & 5.99 & 0.85 & 7.96 & 1.21 & 1.73 & 8.81 & 0.085 \\
\cline { 2 - 11 } & Wet & 12.5 & 19.9 & 2.54 & 0.75 & 3.77 & 0.54 & 0.91 & 4.52 & 0.191 \\
\cline { 2 - 11 } & Flood & 8.8 & 16.3 & 1.45 & 0.75 & 2.20 & 0.34 & 0.56 & 2.96 & 0.266 \\
\hline $\begin{array}{c}\text { Flow- } \\
\text { weighted } \\
\text { mean }\end{array}$ & Dry & 55.1 & 86.2 & 9.78 & 0.56 & 13.73 & 1.79 & 2.72 & 14.29 & \\
\cline { 2 - 11 } & Wet & 16.3 & 24.4 & 3.81 & 0.57 & 5.34 & 0.76 & 1.21 & 5.91 & \\
\cline { 2 - 11 } & Flood & 14.1 & 22.0 & 2.32 & 0.56 & 3.47 & 0.52 & 0.86 & 4.03 & \\
\hline
\end{tabular}

Table 4 and 5 show that for all parameters except $\mathrm{NO}_{3}$, the flow-weighted mean concentration is larger than average concentration, caused by several relatively big rivers to Deep Bay which had bigger flow rate and were heavily polluted (Yuen Long Creek, Kam Tin River, River Ganges and River Beas). The water quality during floods is best, then wet season, and the worst in dry season. Correspondingly, the average flow rate is biggest for flood samples, then wet season, and smallest in dry season. Therefore, the overall water quality in Hong Kong region or these 37 rivers belongs to the type of dilution.

\section{Integrated mean concentration of each Water Control Zone}

On the basis of Table 1, the integrated mean concentration for each Water Control Zone can be obtained with the concentrations of all rivers in the zone by taking the average flow of each river as its weight, Table 6. Obviously, the worst water quality occurs in Deep Bay, its integrated mean concentrations are much higher than those of other zones.

\section{NUTRIENT LOAD ESTIMATION}

\section{Load estimation methods}

Since the sample measurements of concentrations reflect the actual influences from all aspects in upland area. Therefore, the above results of mean concentrations can be applied for the load estimation of nutrients. The following methods will be applied:

- Methods based on mean concentration: load=runoff volume $\times$ mean concentration

Mean concentration 1: runoff $\times$ average concentration

Mean concentration 2: runoff $\times$ flow-weighted mean concentration

Mean concentration 3: wet season load + dry season load

Sub-zone mean con.: sum of load from sub-zones 
- Methods based on mean concentration and land use

Classified land-use mean concentration: sum of load from each land use

Table 6 Integrated mean concentration of each Water Control Zone

\begin{tabular}{|l|r|r|r|r|r|r|r|c|}
\hline \multirow{3}{*}{ Water Control Zone } & \multicolumn{1}{|c|}{$\mathrm{BOD}_{5}$} & $\mathrm{COD}$ & \multicolumn{1}{c|}{$\mathrm{NH}_{4}$} & \multicolumn{1}{c|}{$\mathrm{NO}_{3}$} & \multicolumn{1}{c|}{$\mathrm{TKN}$} & \multicolumn{1}{c|}{$\mathrm{PO}_{4}$} & \multicolumn{1}{c|}{$\mathrm{TP}$} & \multicolumn{1}{c|}{$\mathrm{TN}$} \\
\cline { 2 - 10 } & $(\mathrm{mg} / \mathrm{l})$ & $(\mathrm{mg} / \mathrm{l})$ & $(\mathrm{mg} / \mathrm{l})$ & $(\mathrm{mg} / \mathrm{l})$ & $(\mathrm{mg} / \mathrm{l})$ & $(\mathrm{mg} / \mathrm{l})$ & $(\mathrm{mg} / \mathrm{l})$ & $(\mathrm{mg} / \mathrm{l})$ \\
\hline \hline DEEP BAY & 40.5 & 53.6 & 9.59 & 0.33 & 13.04 & 1.81 & 2.77 & 13.37 \\
\hline JUNK BAY & 2.3 & 7.9 & 0.18 & 1.79 & 0.52 & 0.22 & 0.27 & 2.31 \\
\hline NORTH WESTERN & 21.7 & 46.4 & 2.79 & 0.97 & 4.11 & 0.46 & 1.00 & 5.09 \\
\hline PORT SHELTER & 1.0 & 6.1 & 0.07 & 0.57 & 0.22 & 0.06 & 0.07 & 0.79 \\
\hline SOUTHERN & 2.5 & 37.2 & 0.20 & 0.16 & 0.54 & 0.08 & 0.15 & 0.70 \\
\hline TOLO HARBOUR \& CHANNEL & 5.1 & 16.6 & 0.22 & 0.77 & 0.86 & 0.09 & 0.26 & 1.63 \\
\hline IICTORIA HARBOUR & 8.9 & 19.2 & 1.15 & 1.08 & 2.09 & 0.13 & 0.34 & 3.17 \\
\hline WESTERN BUFFER & 2.4 & 10.9 & 0.32 & 1.63 & 0.74 & 0.18 & 0.22 & 2.38 \\
\hline
\end{tabular}

\section{Annual load estimation of Hong Kong region}

There are 6 specific methods of load estimation can be used for the whole area of Hong Kong. The methods and their results are shown in Table 7. Analysis shows that the accuracy of load estimation depends strongly on the accuracy of flow runoff (Huaien Li, et al. 2002). So the runoff, in all kinds of mean concentration methods, was estimated with runoff coefficient and annual rainfall. Using the data of annual runoff and rainfall from 11 hydrological stations and their watersheds in Hong Kong, the area-weighted runoff coefficient of the water year of 1998 is 0.66. Compared to the mean annual runoff coefficients of whole Pearl River, 0.51, and Pearl Delta, 0.56, the annual runoff coefficient for Hong Kong, 0.66, is acceptable. Since the rainfall in water year 1998 is close to mean annual rainfall, the mean runoff coefficient is more or less 0.66 for Hong Kong region. The value of annual rainfall was taken from the record of station at Hong Kong Observatory. Though different methods or treatments can get very different results, we can see from Table 7: the results of divided the year into wet and dry seasons should be more reasonable than ones of whole year; on spatial treatment, the results of sub-zones should be more reasonable than whole region; for urban areas, more reasonable the results of two kinds, instead of one type. Therefore, the results of methods with the order No.3, 4 and 5 in Table 7 are more reasonable and can be considered as the final values of total annual load in Hong Kong region in 1998. That is to say, about 8000 tons of TN, 1500 tons TP, and 20,000 tons BOD 5 are transported into sea from Hong Kong's land in 1998.

Table 7 Total annual load estimation for the whole area of Hong Kong area, 1998

\begin{tabular}{|c|l|c|c|c|l|}
\hline Order & \multicolumn{1}{|c|}{ Method } & TN (ton) & TP (ton) & BOD $_{5}$ (ton) & \multicolumn{1}{|c|}{ Remarks } \\
\hline \hline 1 & Mean concentration 1 & 10188.9 & 2032.3 & 27322.2 & average concentration \\
\hline 2 & Mean concentration 2 & 12611.0 & 2516.8 & 39632.9 & flow-weighted mean concentration \\
\hline 3 & Mean concentration 3 & 8186.0 & 1511.0 & 17865.7 & average wet \& dry concentration \\
\hline 4 & Sub-zone mean con. & 8582.5 & 1595.0 & 25119.3 & Deep Bay+other area \\
\hline 5 & Classified land-use mean con & 6248.4 & 1147.2 & - & Town + urban ${ }^{* 1}$ \\
\hline 6 & Classified land-use mean con & 10505.3 & 1993.1 & - & Town \\
\hline
\end{tabular}

Notes: *1: "Town" including North District, Yuen Leng, Tuen Mun and Tai Po, using the values of concentrations carried out by this study; "urban" means the other part of town and urban, using the values of concentrations carried out by Chen, et al., 1999.

*2: Using the values of concentrations carried out by this study for all areas of town and urban.

The results of sub-zone mean concentration method show that most nutrient loads are from Deep Bay, Fig.1.

Taking the example of classified land-use mean concentration method, we can compare the distribution of different land uses and the distribution of loads from different land uses, Table 8. Obviously, the loads of nutrients mainly come from the areas of agriculture, towns.

\section{CONCLUSIONS}

In order to fully understand and predict the red tides and eutrophication in coastal waters around Hong Kong, it is necessary to study the characteristics of nonpoint source pollution and estimate the nutrient loads. Based on monthly river water quality measurements, rainfall and river flow data, land uses, and other related information, mean concentrations were carried out for different land uses, each Water Control Zone, and Hong Kong region. Then, the annual nutrient loads were estimated with various methods for the whole area of Hong Kong, and about 8000 tons of TN and 1500 tons TP are transported into coastal waters from Hong Kong's land in 1998. The rainfall of 1998, 2334mm, is close to mean annual 
value $(2214 \mathrm{~mm})$. If the situation of land use and pollution control keeps no change, the NSP loads of wet year and dry year will be much greater and smaller than that of 1998 , respectively.

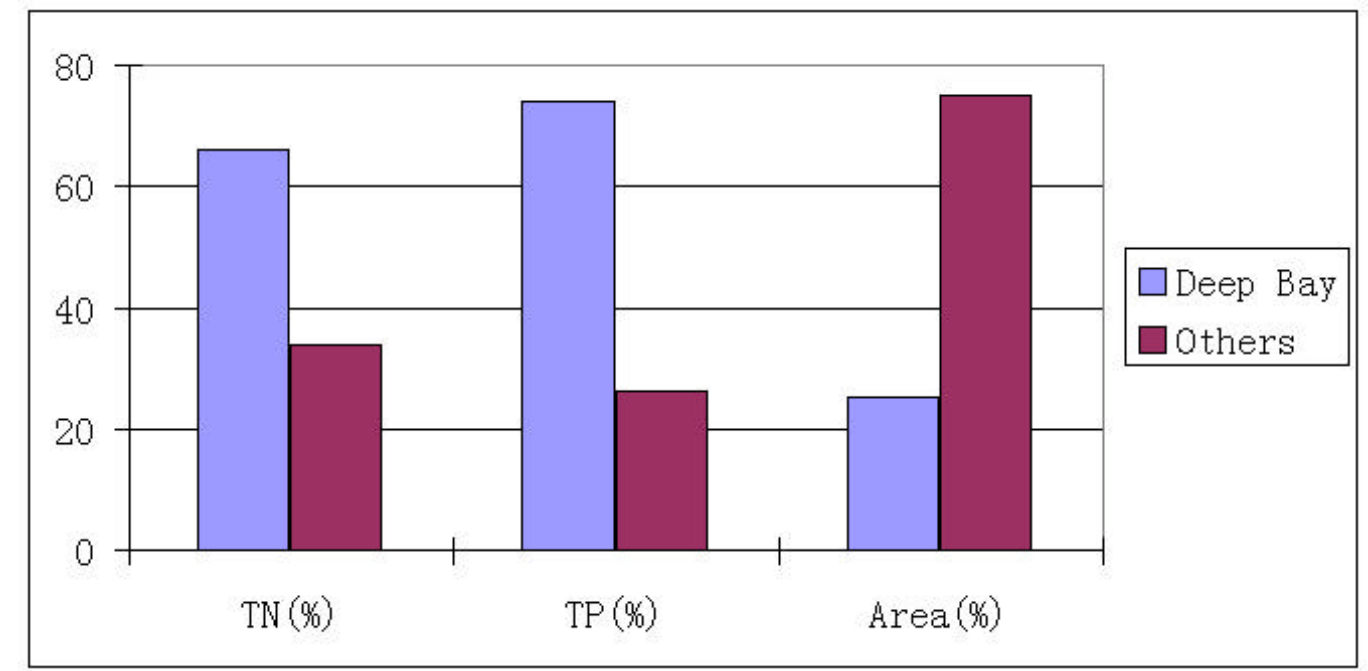

Fig.1 Comparison of TN, TP, and area between Deep Bay and other part

Table 8 Area and TN load distribution of different land uses in Hong Kong region

\begin{tabular}{|l|c|c|c|c|}
\hline \multirow{2}{*}{ Land use } & \multicolumn{2}{|c|}{ TN Load } & \multicolumn{2}{c|}{ Area } \\
\cline { 2 - 5 } & ton & $\%$ & $\mathrm{Km}^{2}$ & $\%$ \\
\hline \hline Towns & 1693 & 27.1 & 181 & 16.5 \\
\hline Agri. & 2179 & 34.9 & 72 & 6.6 \\
\hline Wood & 237 & 3.8 & 220 & 20.1 \\
\hline Shrub & 494 & 7.9 & 229 & 20.9 \\
\hline Grass & 1083 & 17.3 & 290 & 26.4 \\
\hline Bad & 296 & 4.7 & 65 & 5.9 \\
\hline Water & 266 & 4.3 & 40 & 3.6 \\
\hline Total & 6248 & 100.0 & 1097.0 & 100.0 \\
\hline
\end{tabular}

The woodland, shrubland and grassland, $739 \mathrm{~km}^{2}$ or $67.3 \%$, cover the major part of whole Hong Kong region. In which, the country parks and natural reserves take the area of $415 \mathrm{~km}^{2}$. This is beneficial to the control of NSP since the human activities are/will be limited strictly in these areas.

At present, the key of NSP control in Hong Kong is the waste from livestock farms and unsewaged villages. With the full implementation of WSPs and Livestock Waste Control Scheme, the NSP will mainly come from urban/town area, with very high density of population, in Hong Kong. It is urgent to study and control the NSP systematically, including the monitoring, modeling, predicting, managing and controlling of NSP.

\section{REFERENCES}

Arega, F., 2000. A diagenetic two-layer eutrophication model for Tolo Harbour, Hong Kong. A thesis submitted in partial fulfillment of the requirements for the degree of Ph.D. at the University of Hong Kong. 193-200.

Chen, J.W.J., et al., 1999. A Pilot study on urban storm water pollution in Hong Kong. Proceedings of International Conference on Urban Pollution Control Technology, 13-15 October 1999, Hong Kong, 443-448.

EPD (Environmental Protection Department of HKSAR), 2000. River Water Quality in Hong Kong in 1999.

Frink, C.R., 1991. Estimating nutrient exports to estuaries. Journal of Environmental Quality 20, 717-724.

ISD (Information Services Department of HKSAR), 2000, Hong Kong 1998 (Year Book), 470.

Letcher, R.A., et al., 2002. A comparison of catchment water quality models and direct estimation techniques. Environmental Modelling \& Software 17, 77-85.

Lee, J.H.W., 1990. Pollution load due to storm runoff in Hochung river and Hebe haven. Report for

Li H., et al., 2002. Comparison and improvement of nutrient load estimation methods for rivers. Proceedings of Second International Workshop on Coastal Eutrophication, November 21-24, 2002, Tianjin, China, pp112-117.

Novotny, V., Olem, H., 1994. Water quality: prevention, identification, and management of diffuse pollution. Van Nostrand Reinhold. New York.

Peart, M.R., Jayawardena, A.W., 1991. Storm period water quality changes in a small stream near Shek Kong, Hong Kong. Lee \& Cheung (eds), Environmental Hydraulics, Balkema, Rotterdam.

WSD (Water Supplies Department of HONG KONGSAR), 2001. Hong Kong Rainfall and Runoff, Vol. 34 \& 35. 